\title{
ANALISIS KETERKAITAN PENGAKUAN PENDAPATAN DAN LABA PADA PERUSAHAAN KONSTRUKSI YANG TERDAFTAR DI BURSA EFEK INDONESIA
}

\author{
Iswadi $^{1}$, Khirnika $^{2}$ \\ ${ }^{1,2}$ Prodi Akuntansi Fakultas Ekonomi dan Bisnis Universitas Malikussaleh Lhokseumawe \\ iswadi@unimal.ac.id
}

\begin{abstract}
This study aimed to determine the effect of operating income recognition on the income statement. The data used were secondary data in form of the income statements of construction companies listed on the Indonesia Stock Exchange (IDX) from 2013 to 2016. The objects in this study were selected based on the highest profit value and were taken 3 companies as the sample. This study uses descriptive analysis as data analysis. The results showed that the three companies, namely PT Pembangunan Perumahan, PT Surya Semesta Internusa Tbk, and PT Waskita Karya Tbk, measured their income by using the percentage settlement method and each had a different level of income each year and were in accordance with the applicable accounting standars namely Standard Statement Financial Accounting (PSAK No. 34).
\end{abstract}

Keywords: Revenue Tecognition, PSAK No. 34, Percentage of Settlement.

\section{PENDAHULUAN}

Laporan rugi laba merupakan salah satu alat yang memberikan informasi penting yang dapat digunakan untuk melihat prestasi kerja perusahaan selama satu periode akuntansi (Fitriana, 2015). Perusahaan berlomba-lomba untuk meningkatkan pendapatan mereka karena dengan meningkatnya pendapatan akan meningkatkan laba, dimana laba tersebut nantinya akan digunakan untuk keperluan perusahaan. Pihak-pihak yang berkepentingan dengan badan usaha tersebut pada setiap akhir periode akuntansi dapat menilai prestasi kerja manajemen berdasarkan laporan keuangan yang diterbitkan (Ningsih, 2014).

Apabila pendapatan tidak diakui pada saat yang tepat, informasi laba yang tersaji dalam laporan keuangan akan dinyatakan terlalubesar atau terlalu kecil, menyebabkan laporan keuangan terutama laporan laba rugitidak mencerminkan keadaan yang sebenarnya terjadi selama periode laporantersebut(Rismansyah dan Safitri, 2015). Dengan demikian pemakai laporan akan salah memprediksi dan menyebabkan mereka keliru dalam mengambil keputusan dikarenakan informasi yang salah.

Pada perusahaan kontraktor, pengakuan pendapatan juga menjadi masalah yang penting. Hal ini disebabkan oleh pekerjaan kontraktor atau proyek yang dikerjakan memiliki jangka waktu penyelesaian yang bervariasi (Fitriana, 2015). Hal ini mengakibatkan masalah dalam pengakuan dan pengukuran pendapatan karena sering kali laporan keuangan harus dibuat tapi pekerjaan belum selesai, untuk itu perlu dibuat penaksiran beberapa pendapatan yang diakui sebagai pendapatan untuk tahun berjalan. Kesalahan dalam pengakuan dan pengukuran pendapatan akan mengakibatkan perhitungan laba rugi yang tidak tetap dan hal ini dapat menyebabkan kesalahan dalam pengambilan keputusan bagi pengguna laporan keuangan perusahaan.

Hal ini mengakibatkan masalah dalam pengakuan dan pengukuran pendapatankarena sering kali laporan keuangan harus dibuat tapi pekerjaan belum selesai, untuk itu perludibuat penaksiran beberapa pendapatan yang diakui sebagai pendapatan untuk tahun berjalan.Menurut Ningsih (2014), kesalahan dalam pengakuan dan pengukuran pendapatan akan mengakibatkan perhitungan labarugi yang tidak tetap dan hal ini dapat menyebabkan kesalahan dalam pengambilan keputusanbagi pengguna laporan keuangan perusahaan.

Salah satu informasi yang perlu diperhatikan dalam menyusun laporan keuangan padalaporan laba rugi adalah pengakuan pendapatan. Dalam mengakui pendapatan dan bebandiperusahaan kontraktor, perusahaan harus menggunakan metode yang benar sehinggakeuntungan yang diperoleh dilaporkan secara wajar sesuai dengan nilai sesungguhnya (Fitriana, 2015). Untuk ituagar tidak menyesatkan para pemakai laporan keuangan, maka laporan keuangan tersebut harusdisusun sesuai dengan Standar Akuntansi Keuangan khususnya ketetapan pengankuanpendapatan kontrak dan beban kontrak 
yang diatur dalam Pernyataan Standar AkuntansiKeuangan (PSAK) No. 34 (Yastiar, 2014).

Dalam hal pengakuan pendapatan dan beban dari perusahaan konstruksi sesungguhnya telah diatur dalam Pernyataan Standar Akuntansi Keuangan (PSAK) No. 34 (Revisi 2010), dalam pernyataan tersebut dinyatakan bahwa, " kontrak konstruksi adalah suatu kontrak yang dinegosiasikan secara khusus untuk konstruksi suatu aset atau suatu kombinasi aset yang berhubungan erat satu sama lain atau saling tergantung dalam hal rancangan, teknologi, dan fungsi atau tujuan pokok penggunaan" (Lestari dan Dewi, 2016).

Terdapat dua metode pengakuan pendapatan dan beban perusahaan konstruksi, yaitu metode persentase penyelesaian dan metode kontrak selesai. Metode persentase penyelesaian mengakui pendapatan, biaya, dan laba kotor sesuai dengan persentase pekerjaan yang telah diselesaikan dalam tiap periode. Metode kontrak selesai mengakui pendapatan apabila kontrak telah selesai dikerjakan (Skousen, 2004:592).

Penerapan metode pengakuan dan beban mempunyai pengaruh dalam perhitungan laba rugi perusahaan, apabila penerapan metode pengakuan pendapatan dan beban tidak tepat maka akan menyajikan laporan keuangan yang tidak mencerminkan kinerja perusahaan yang sesungguhnya. Ketepatan perlakuan akuntansi dalam mengakui pendapatan dan beban sangat berpengaruh pada kewajaran yang dilaporkan dalam laporan laba rugi periodik, dimana laporan laba rugi periodik melaporkan besarnya pendapatan dan pembebanan biaya yang diakui dalam satu periode (Datulangie dan Poputra, 2015).

Penelitian ini mengambil objek pada perusahaan konstruksi. Perusahaan konstruksi dipilih karena memiliki karakteristik yang khas, dimana proses pekerjaan proyek tidak semuanya terselesaikan dalam satu periode akuntansi dan awal pekerjaan tidak mungkin dipastikan dimulai di awal tahun (Fitriana, 2015). Sehingga terdapat beberapa metode yang digunakan perusahaan untuk mengakui pendapatannya.

Penerapan metode pengakuan dan beban mempunyai pengaruh dalam perhitungan laba rugi perusahaan, apabila penerapan metode pengakuan pendapatan dan beban tidak tepat maka akan menyajikan laporan keuangan yang tidak mencerminkan kinerja perusahaan yang sesungguhnya.

Penelitian ini merupakan penelitian ulang atau replikasi dari penelitian yang dilakukan oleh Lestari dan Dewi (2014) dengan judul pengaruh pengakuan pendapatan dan beban perusahaan terhadap laporan laba rugi pada perusahaan konstruksi. Persamaan dalam penelitian terdahulu dengan penelitian ini adalah sama-sama meneliti pengakuan pendapatan pada perusahaan jasa kontruski, sedangkan perbedaanya terletak pada objek penelitian, penelitian sebelumnya hanya pada satu perusahaan yaitu di PT Sumber Barokah, sedangkan penelitian sekarang yaitu pada perusahaa konstruksi yang terdaftar di Bursa Efek Indonesia yang terdiri dari tiga perusahaan yaitu PT Pembangunan Perumahan (Persero) Tbk, PT Surya Semesta Internusa Tbk, dan PT Waskita Karya (Persero) Tbk.

Alasan memilih ketiga perusahaan tersebut karena merupakan perusahaan dengan laba tertinggi dimana kinerja manajemen perusahaan tercermin pada laba yang terkandung dalam salah satu laporan keuangan, yaitu laporan laba rugi. Oleh karena itu proses penyusunan laporan laba rugi dipengaruhi oleh faktor-faktor tertentu yang dapat menentukan kualitas laporan tersebut.

\section{TINJAUAN PUSTAKA}

\section{Laporan Laba Rugi}

laporan laba rugi adalah penjelasan lengkap dan lebih rinci tentang penghitungan laba rugi. Laporan laba rugi melaporkan seluruh hasil dan biaya untuk mendapatkan hasil, dan laba rugi perusahaan selama satu periode tertentu (Fitriana, 2015).

Laporan laba atau rugi yang dibuat oleh bagian akuntansi untuk digunakan kepada pihak bagian terkait yang membutuhkan laporan laba rugi perusahaan. Diantaranya adalah dapat menginformasikan jumlah total pajak yang harus dibayarkan oleh perusahaan, memberikan informasi histori dari perolehan laba atau rugi semua periode dan untuk menjadi referensi evaluasi bagi manajemen perusahaan untuk menetapkan langkah-langkah apa saja yang harus diambil di periode yang akan datang, danjuga untuk memberikan informasi apakah langkah yang ditempuh menjadi efisien atau tidak dari besaran beban atau biaya perusahaan(Harahap, 2011:46)

Ada dua bentuk laporan laba rugi yang umumnya dipergunakan dalam aktivitas pelaporan keuangan perusahaan, yaitu single step dan multiple step (Ardiyos, 2011:267). Dalam bentuk single step, pendapatan dikurangkan dengan biaya untuk menghitng laba bersih atau rugi bersih. Jadi, hanya ada dua pengelompokkan, yaitu pendapatan dan biaya. Sedangkan dalam bentuk multiple step, unsurunsur pendapatan dan biaya diklasifikasikan menurut sumbernya, dalam kaitannya dengan kegiatan atau usaha pokok perusahaan. Secara umum laporan laba rugi bentuk bertahap menunjukkan adanya pemisahan hasil usaha (labarugi) menurut sumbernya, misalnya pemisahan dari sumber aktivitas operasi dan non operasi perusahaan. 


\section{Pendapatan}

Pendapatan merupakan peningkatan manfaat ekonomi selama satu periode akuntansi tertentu dalam bentuk pemasukan atau penambahan aktiva atau penurunan kewajiban yang mengakibatkan kenaikan ekuitas, yang tidak berasal dari kontribusi penanaman modal. Peningkatan jumlah aktiva atau penurunan kuajiban dapat berasal dari penyerahan barang atau jasa atau aktivitas usaha lainnya dalam satu periode.

Ikatan Akuntan Indonesia dalam Pernyataan Standar Akuntansi Keuangan PSAK No. 23 (Revisi 2009) mendefinisikan pendapatan sebagai berikut: "Pendapatan adalah arus masuk bruto dari manfaat ekonomi yang timbul dari aktivitas normal perusahaan selama suatu periode bila arus masuk itu mengakibatkan kenaikan ekuitas yang tidak berasal dari kontribusi penanam modal.'Jadi, pendapatan dapat diartikan sebagai hasil kegiatan normal suatu badan usaha atau perusahaan tertentu, seperti penjualan barang, pemberian jasa, atau sumbersumber lain yang dijual kepada konsumen, atau kegiatan yang bersifat insidentil, bukan penambahan aktiva yang berasal dari penanam modal baru dari pemilik, dan juga bukan pula penanaman harta yang disebabkan karena penambahan utang.

Pendapatan kontrak diukur pada nilai wajar dari imbalan yang diterima atau yang akan diterima. Pengukuran pendapatan kontrak dipengaruhi oleh bermacam-macam ketidakpastian yang bergantung pada hasil dari peristiwa masa depan (Prianthara, 2010). Nilai wajar adalah suatu jumlah yang timbul dari suatu transaksi penukaran aktiva atau jasa yang biasanya ditentukan oleh persetujuan antara perusahaan dan pembeli atau pemakai aktiva tersebut. Jumlah pendapatan diukur dengan nilai wajar imbalan yang diterima atau yang dapat diterima perusahaan dikurangi dengan diskon dagang dalam rabat volume yang diperbolehkan perusahaan (Saputra \& Effendi, 2013).

Pengakuan pendapatan dimaksudkan untuk melaporkan pendapatan dalam laporan keuangan yang dibuat secara periodik. Masalah pengakuan pendapatan berkaitan dengan saat yang tepat untuk melaporkannya sebagai pendapatan (Sapto dan Elly, 2012). Oleh karena diperlukannya suatu keputusan yang tepat dari pihak manajemen, saat kapan pendapatan harus diakui atau direalisasikan, dan kondisi apa saja yang harus dipenuhi agar pendapatan diakui atau direalisasi (Ningsih, 2014).

Salah satu permasalahan utama dari elemen pendapatan adalah proses pengakuan pendapatan (revenue recognition). Pengakuan (recognition) mengacu pada saat atau waktudimana suatu transaksi tersebut, baik dalam kata-kata maupun jumlahnya, dimana jumlahnya mencakup angka-angka ringkas yang dilaporkan dalam laporan keuangan (Datulangie dan Poputra, 2015).

\section{Kerangka Konseptual}

Pada transaksi di perusahaan jasa konstruksi harus adanya metode penyelesaian kontrak. Dalam hal ini perusahaan menggunakan metode persentase penyelesaian karena pendapatan dan laba kotor diakui setiap periode berdasarkan kemajuan proses konstruksi (Ningsih, 2014).Gambaran kerangka konseptual pada penelitian ini dapat dilihat pada gambar 2.1 berikut:

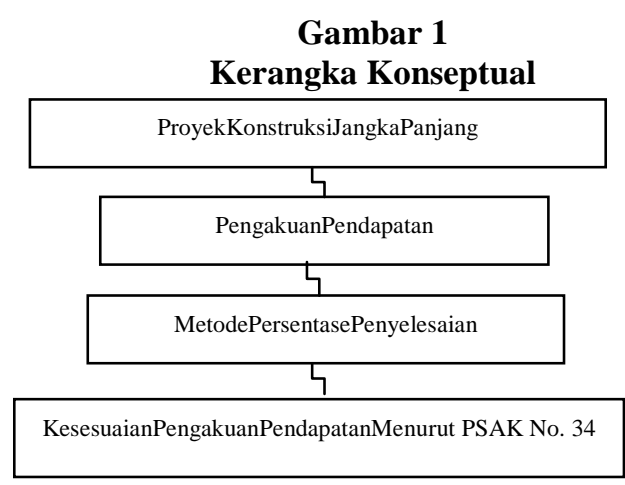

\section{METODE PENELITIAN}

Objek penelitian skripsi ini adalah data mengenai pendapatan operasional pada laporan laba rugi di perusahaan konstruksi yang terdaftar di Bursa Efek Indonesia (BEI) selama periode 2013-2016 sebanyak 3 perusahaan yaitu PT Pembangunan Perumahan (Persero) Tbk, PT Surya Semesta Internusa Tbk, dan PT Waskita Karya (Persero) Tbk. Jenis data yang digunakan dalam penelitian ini adalah jenis data sekunder. Adapun metode pengumpulan data yang digunakan yaitu metode dokumentasi dan studi pustaka.

Dalam penelitian ini analisis data yang digunakan adalah analisis deskriptif. Data-data yang berupa angka dalam penelitian ini hanya bertujuan untuk mengorganisasikan, mengikhtisarkan, dan menyajikan data melalui cara yang lebih informatif.

\section{Operasionalisasi Variabel}

Operasionalisasi variabel diperlukan untuk menjabarkan variabel penelitian menjadi konsep, dimensi, indikator dan ukuran yang diarahkan untuk memperoleh nilai variabel lainnya. Disamping itu, tujuannya adalah untuk memudahkan pengertian dan menghindari perbedaan persepsi dalam penelitian ini. Berikut adalah operasionalisasi variabel dari penelitian ini:

Tabel 1 Rincian Operasional Variabel Penelitian

\begin{tabular}{|c|l|l|}
\hline No & \multicolumn{1}{|c|}{$\begin{array}{c}\text { Variabel } \\
\text { Penelitian }\end{array}$} & \multicolumn{1}{|c|}{ Indikator } \\
\hline 1 & $\begin{array}{l}\text { Laporan Laba } \\
\text { Rugi (Lestari } \\
\text { dan Dewi, } \\
\text { 2016) }\end{array}$ & $\begin{array}{l}\text { Penerapan PSAK No. 34 atas pengakuan } \\
\text { pendapatan terhadap laporan laba rugi telah } \\
\text { sesuai. }\end{array}$ \\
\end{tabular}




\begin{tabular}{|c|c|c|}
\hline 2 & $\begin{array}{l}\text { Pengakuan } \\
\text { Pendapatan } \\
\text { (Lestari dan } \\
\text { Dewi, 2016) }\end{array}$ & $\begin{array}{l}\text { Pengakuan pendapatanperusahaan } \\
\text { menggunakan metode persentase } \\
\text { penyelesaian dengan ukuran output. } \\
\text { Pengakuan pendapatan serta metode } \\
\text { pencatatan dan pengukuran yang diterapkan } \\
\text { oleh perusahaan sudah sesuai dengan standar } \\
\text { akuntansi yang berlaku yaitu Pernyataan } \\
\text { Standard Akuntansi Keuangan(PSAK) dalam } \\
\text { hal ini yang terkait dengan kontrak konstruksi } \\
\text { adalah PSAK No. 34. }\end{array}$ \\
\hline
\end{tabular}

Sumber : Diolah dari berbagai referensi

\section{HASIL DAN PEMBAHASAN}

\section{Perhitungan Nilai Kontrak}

Pada perusahaan jasa konstruksi, pengukuran pendapatan adalah berdasarkan kontrak yang ditandatangani oleh pihak kontraktor dengan pihak pemberi kerja (Fitriana, 2015). Jumlah kontrak tersebut merupakan harga jual dari pekerjaan yang akan dilakukan. Jumlah kontrak pada PT Pembangunan Perumahan (Persero) Tbk, PT Surya Semesta Internusa Tbk, dan PT Waskita Karya (Persero) Tbk ditentukan berdasarkan dokumen tender proyek yang diolah oleh bagian cost estimation.

Dalam menentukan jumlah harga penawaran, yang dilakukan adalah mengkalkulasikan biaya langsung yang akan dikeluarkan pada saat pelaksanaan proyek. Kalkulasi biaya-biaya tersebut harus didasarkan pada perhitungan yang paling rasional dan efisien, karena dalam pelelangan akan bersaing dengan kontraktor lain. Untuk menetapkan siapa yang akan memenangkan lelang umumnya didasarkan pada biaya yang terendah atau paling menguntungkan bagi pemberi kerja, serta juga pada saat teknis yang harus dapat dipertanggungjawabkan. Untuk itu, perlu diadakan perhitungan biaya tidak langsung, laba yang diharapkan, dan jumlah biaya pengawas lapangan.

\section{Pengaruh Pengakuan Pendapatan Operasional terhadap Laporan Laba Rugi}

\section{PT Pembangunan Perumahan(Persero) Tbk}

Pendapatan atas jasa konstruksi diakui berdasarkan persentase penyelesaian pekerjaan. Persentase penyelesaian konstruksi ditetapkan berdasarkan kemajuan fisik proyek yang dituangkan dalam Laporan Prestasi Proyek (LPP) yang ditandatangani kedua belah pihak. Terhadap pendapatan usaha konstruksi yang telah diterbitkan fakturnya diakui sebagai piutang usaha, sedangkan yang belum diterbitkan fakturnya diakui sebagai tagihan bruto pemberi kerja. Berikut adalah tabel hasil pendapatan dan laba bersih pada PT Pembangunan Perumahan (Persero) Tbk periode 2013-2016 dijelaskan pada tabel 2 berikut:
Tabel 2

Jumlah Pendapatan dan Laba Bersih periode 2013-2016

\begin{tabular}{|c|c|c|}
\hline Tahun & Pendapatan & Laba Bersih \\
\hline 2013 & 11.655 .844 .311 .524 & 420.719 .976 .436 \\
\hline 2014 & 12.427 .371 .312 .550 & 532.065 .270 .922 \\
\hline 2015 & 14.217 .372 .867 .769 & 2.037 .652 .190 .533 \\
\hline 2016 & 16.458 .884 .219 .698 & 1.277 .066 .025 .557 \\
\hline Sumber: Data diolah (2018)
\end{tabular}

Berdasarkan pada tabel 2 diatas, jumlah tingkat pendapatan pada tahun 2013 berjumlah Rp11.655.844.311.524 dengan total laba bersih sebesar Rp420.719.976.436. Pada tahun 2014 jumlah pendapatan PT Pembangunan Perumahan (Persero) Tbk meningkat menjadi Rp12.427.371.312.550 dengan total laba bersih sebesar Rp 532.065.270.922. Sedangkan untuk tahun 2015 jumlah pendapatan perusahaan meningkat sebesar Rp 14.217.372.867.769 dengan total laba bersih meningkat menjadi sebesar Rp 2.037.652.190.533. Akan tetapi, ditahun 2016 laba bersih PT Pembangunan Perumahan (Persero) Tbk mengalami penurunan dengan jumlah pendapatan meningkat sebesar Rp 16.458.884.219.698 sedangkan total perolehan laba bersih menurun menjadi sebesar Rp1.277.066.025.557.

Menurut Analis Mirae Asset Sekuritas Franky Rivan mengatakan, pertumbuhan laba PT Pembangunan Perumahan (Persero) Tbk yang tak sebanyakdengan para kompetitornya dikarenakan perolehan kontrak barunya yang tidak seberapa, yakni hanya naik 13 persen atau menjadi Rp 2,92 triliun. Namun demikian, menurut Franky, bukan berarti perusahaan tidak mampu memperoleh kontrak baru. Ia berpendapat, proses tender perusahaan belum mencapai kesepakatan. Karena, beberapa proyek yang diincar oleh PT Pembangunan Perumahan (Persero) Tbk berbentuk pembangunan bandara dan pelabuhan. Lain halnya dengan perusahaan konstruksi lain seperti, PT Adhi Karya, PT Wijaya Karya, dan PT Waskita Karya yang mudah mendapatkan kontrak dikarenakan proyeknya berupa gedung atau jalan tol. Sedangkan PT Pembangunan Perumahan (Persero) Tbk ini pelabuhan dan bandara yang tendernya cukup lama. PT Pembangunan Perumahan (Persero) Tbk baru akan mendapatkan nilai kontrak baru dengan pertumbuhan yang melejit pada kuartal II mendatang. Hal ini disebabkan nilai kontrak dari pelabuhan dan bandara lebih besar jika dibandingkan dengan proyek gedung atau jalan tol.

Menurut Hanafi dan Halim (2012) menyatakan bahwa pertumbuhan laba dipengaruhi oleh salah satunya yaitu tingkat pendapatan. Tingkat pendapatan dimasa lalu yang tinggi, maka semakin tinggi tingkat pendapatan dimasa yang akan datang sehingga pertumbuhan laba semakin tinggi. Akan tetapi, kenyatannya tidak sesuai dengan yang terjadi pada PT Pembangunan Perumahan (Persero) Tbk dimana pendapatan tahun 2015 yang tinggi juga 
berpengaruh terhadap pendapatan tahun 2016. Namun laba tahun 2016 tidak mengalami peningkatan. Hal ini berarti bahwa tingkat pendapatan dimasa lalu tidak terlalu berpengaruh terhadap meningkatnya jumlah laba tahun yang akan datang.

Penelitian ini sejalan dengan penelitian Lestari dan Dewi (2016) yang menyatakan perusahaanharus menerapkan persentase penyelesaian dalam pengakuan pendapatan sehingga dapat diketahui laporan laba rugi yang disajikan oleh perusahaan sudah memenuhi prinsip matching concept dimana pendapatan yang diakui terdapat pula biaya yang diakui perusahaan.

\section{PT Surya Semesta Internusa Tbk}

Pendapatan jasa konstruksi meliputi nilaipendapatan semula yang disetujui dalam kontrakdan diakui dengan menggunakan metodepersentase penyelesaian (percentage ofcompletion method) pada tanggal laporan posisikeuangan. Dalam hal ini persentase penyelesaian konstruksi ditetapkan berdasarkan kemajuan fisik. Beban jasa kontruksi meliputi biayabiaya yang dapat diatribusikan kepada suatu kontrak untuk jangka waktu sejak tanggal kontrak diperoleh sampai dengan penyelesaian akhir kontrak dan diakui dalam laporan laba rugi komprehensif konsolidasian tahun berjalan sesuai dengan hasil survei pekerjaan yang telah dilaksanakan. Berikut adalah tabel hasil pendapatan dan laba bersih pada PT Surya Semesta Internusa Tbk periode 2013-2016 dijelaskan pada tabel 3 berikut:

Tabel 3

Jumlah Pendapatan dan Laba Bersih periode 2013-2016

\begin{tabular}{|c|c|c|}
\hline Tahun & Pendapatan & Laba Bersih \\
\hline 2013 & $4,582,741,464,896$ & $746,549,004,643$ \\
\hline 2014 & $4,464,399,987,604$ & $512,570,857,720$ \\
\hline 2015 & $4,867,889,109,212$ & $368,685,614,633$ \\
\hline 2016 & $3,796,963,231,798$ & $80,051,825,799$ \\
\hline
\end{tabular}

Berdasarkan pada tabel 3 diatas, jumlah tingkat pendapatan PT Surya Semesta Internusa Tbk pada tahun 2013 berjumlah Rp 4,582,741,464,896 dengan perolehan laba bersih sebesar Rp746,549,004,643. Ditahun 2014terjadi penurunan jumlah pendapatanmenjadi sebesar Rp 4,464,399,987,604 dan total laba bersih yang menurun sebesar Rp 512,570,857,720. Lain halnya ditahun 2015, jumlah total pendapatan naik menjadi sebesar Rp 4,867,889,109,212 akan tetapi perolehan laba bersih ditahun 2015 tidak naik bahkan menurun menjadi sebesar Rp 368,685,614,633. Dan ditahun 2016 terjadinya penurunan yang cukup banyak yang diperoleh oleh PT Surya Semesta Internusa Tbk dengan jumlah total pendapatan hanya sebesar Rp $3,796,963,231,798$ dan total perolehan laba bersih yang turun menjadi sebesar Rp 80,051,825,799.
PT Surya Semesta Internusa Tbk mencatatkan pendapatan konsolidasi sebesar Rp 3,7 triliun atau turun $22 \%$ apabila dibandingkan dengan pendapatan perseroan di tahun 2015 yang lalu sebesar Rp 4,8 triliun. Penurunan pendapatan tersebut terutama disebabkan oleh penurunan pendapatan dari unit usaha konstruksi yaitu 30,1\% dibandingkan tahun buku 2015. Di bidang konstruksi, perseroan memaparkan beberapa relaksasi bagi sektor properti yang belum diterjemahkan ke dalam keseluruhan proyek-proyek pembangunan. Sementara itu, di bidang properti pelemahan terjadi karena masih lemahnya pasar properti meski sedikit demi sedikit sedang mengalami pemulihan.

Penurunan ini juga diiringi dengan penurunan laba bersih konsolidasi PT Surya Semesta Internusa Tbk sebesar Rp 62,5 miliar di tahun 2016 atau turun sebesar $79,3 \%$ dibandingkan dengan perolehan laba perseroan di tahun 2015. Penurunan laba ini lantaran perolehan laba di seluruh unit usaha lebih rendah dibandingkan dengan tahun 2015. Bahkan, entitas asosiasi bersama antara Lintas Marga Sedaya mencatatkan kerugian sebesar Rp 99,6 miliar.

Hanafi dan Halim (2012) menyatakan bahwa pertumbuhan laba dipengaruhi oleh tingkat pendapatan. Jika tingkat pendapatan dimasa lalu tinggi, maka semakin tinggi tingkat pendapatan dimasa yang akan datang sehingga pertumbuhan laba semakin tinggi. Pada kenyatannya tidak terjadi pada PT Surya Semesta Internusa Tbk yang mengalami penurunan laba setiap tahunnya dari tahun 2013 sampai dengan tahun 2016. Begitu juga dengan besarnya jumlah pendapatan yang berfluktuatif setiap tahunnya dari tahun 2013 sampai dengan tahun 2016.

Penelitian ini tidak sejalan dengan penelitian yang dilakukan oleh Fitriana (2015) yang menyatakan bahwa dalam mengakui pendapatan perusahaan menerapkan metode kontrak selesai termasuk juga untuk proyek yang terjadi dalam dua periode. Dan penelitian ini sejalan dengan penelitian Lestari dan Dewi (2016) bahwa perusahaan menggunakan metode persentase penyelesaian dengan ukuran output dalam pengakuan pendapatannya dan juga menerapkan metode accrual basic dalam pengakuan setiap transaksinya.

\section{PT Waskita Karya (Persero) Tbk}

Pendapatan dan beban jasa konstruksi diakui dengan menggunakan metode persentase penyelesaian (percentage of completion method) yang diukur berdasarkan kemajuan fisik pada tanggal akhir periode pelaporan yang dinyatakan dalam Berita Acara Penyelesaian Pekerjaan eksternal. Jika kemungkinan besar terjadi total beban kontrak akan melebihi pendapatan kontrak, maka taksiran rugi segera diakui sebagai beban. 
Pendapatan dari usaha perdagangan diakui hanya jika kemungkinan besar manfaat ekonomi sehubungan dengan transaksi tersebut akan mengalir ke entitas berdasarkan metode tahap penyerahan barang kepada pembeli, yang dinyatakan dalam PSAK 23 (Revisi 2010) Pendapatan. Pendapatan dari jasa penyewaan gedung diakui berdasarkan jumlah waktu pemakaian yang telah direalisasikan. Berikut adalah tabel hasil pendapatan dan laba bersih pada PT Waskita Karya (Persero) Tbk periode 2013-2016 dijelaskan pada tabel 4 berikut:

Tabel 4

Jumlah Pendapatan dan Laba Bersih periode 2013-2016

Jumlah Pendapatan dan Laba Bersih periode 2013-2016
\begin{tabular}{|c|c|c|}
\hline Tahun & Pendapatan & Laban Bersih \\
\hline 2013 & $9,686,610,301,864$ & $366,629,440,989$ \\
\hline 2014 & 10.286 .813 .284 .004 & 497.057 .611 .319 \\
\hline 2015 & $14,152,752,847,612$ & $1,567,117,605,791$ \\
\hline 2016 & $23,788,322,626,347$ & $1,809,183,476,256$ \\
\hline
\end{tabular}

Berdasarkan dari tabel 4 diatas, total jumlah pendapatan PT Waskita Karya (Persero) Tbk pada tahun 2013 berjumlah sebesar Rp 9,686,610,301,864 dengan perolehan laba bersih sebesar Rp $366,629,440,989$. Pada tahun 2014 jumlah pendapatan naik menjadi sebesar Rp 10.286.813.284.004 dengan perolehan laba bersih yang meningkat sebesar Rp 497.057.611.319. Ditahun 2015 PT Waskita Karya (Persero) Tbk juga memperoleh jumlah pendapatan yang naik menjadi sebesar Rp 14,152,752,847,612 dengan total laba bersih yang sangat tinggi sebesar Rp $1,567,117,605,791$. Sedangkan pada tahun 2016 jumlah pendapatan tertinggi diperoleh PT Waskita Karya (Persero) Tbk dengan jumlah pendapatan sebesar Rp 23,788,322,626,347 dan total laba bersih yang juga naik menjadi sebesar Rp 1,809,183,476,256 dari tahun sebelumnya.

Kepala Riset PT Koneksi Kapital Alfred Nainggolan menjelaskan alasan meningkatnya pendapatan dan juga laba setiap tahunnya dikarenakan saham perusahaan PT Waskita Karya (Persero) Tbk memiliki nilai valuasi yang lebih rendah dibandingkan perusahaan konstruksi lain seperti PT Pembangunan Perumahan (Persero) Tbk, PT Wijaya Karya, dan PT PT Adhi Karya. PT Waskita Karya (Persero) Tbk memiliki bisnis tol yang dapat membantu mendongkrak kenaikan kinerja perusahaan. Karena itu, tingginya kenaikan kinerja PT Waskita Karya (Persero) Tbk cukup signifikan sejak beberapa tahun terakhir ini karena PT Waskita Karya (Persero) Tbk mengerjakan proyek dengan skala yang besar.

Hal ini sesuai dengan Hanafi dan Halim (2012) yang menyatakan bahwa pertumbuhan laba dipengaruhi oleh tingkat pendapatan dimana jika tingkat pendapatan dimasa lalu tinggi, maka semakin tinggi pula tingkat pendapatan dimasa yang akan datang sehingga pertumbuhan laba semakin tinggi. Pada PT Waskita Karya (Persero) terbukti bahwa setiap tahunnya jumlah pendapatan dari tahun 2013 sampai dengan tahun 2016 selalu meningkat.

Penelitian ini tidak sejalan dengan penelitian Fitriana (2015) yang menunjukkan bahwa dalam mengakui pendapatan perusahaan menerapkan metode kontrak selesai termasuk juga untuk proyek yang terjadi dalam dua periode, dan belum sesuai dengan Pernyataan Standar Akuntansi Keuangan No. 34 tentang kontrak kontruksi. Sedangkan dalam pengakuan beban perusahaannya menggunakan metode accrual basis dan sudah sesuai dengan Pernyataan Standar Akuntansi Keuangan dimana pencatatan beban dilakukan agar tiap periode bisa melaporkan biaya atau beban yang sebenarnya.

\section{Pengakuan Pendapatan menurut PSAK No. 34 (Revisi 2010)}

Menurut PSAK No.34 Paragraf 22. Jika hasil kontrak konstruksi dapat diestimasi secara andal, maka pendapatan kontrak dan biaya kontrak yang berhubungan dengan kontrak konstruksi diakui masing-masing sebagai pendapatan dan beban dengan memerhatikan tahap penyelesaian aktivitas kontrak pada tanggal akhir periode pelaporan. Taksiran rugi pada kontrak konstruksi tersebut segera diakui sebagai beban sesuai dengan paragraf 36 .

Dalam Paragraf 25. Pengakuan pendapatan dan beban dengan memerhatikan tahap penyelesaian suatu kontrak sering disebut sebagai metode persentase penyelesaian. Menurut metode ini, pendapatan kontrak dihubungkan dengan biaya kontrak yang terjadi dalam mencapai tahap penyelesaian tersebut, sehingga pendapatan, beban, dan laba yang dilaporkan dapat diatribusikan menurut penyelesaian pekerjaan secara proporsional. Metode ini memberikan informasi yang berguna mengenai cakupan aktivitas kontrak dan kinerja selama suatu periode

Dalam metode persentase penyelesaian, pendapatan kontrak diakui sebagai pendapatan dalam laba rugi pada periode akuntansi di mana pekerjaan dilakukan. Biaya kontrak biasanya diakui sebagai beban dalam laba rugi pada periode akuntansi di mana pekerjaan yang berhubungan dilakukan. Namun, setiap ekspektasi selisih lebih total biaya kontrak terhadap total pendapatan kontrak segera diakui sebagai beban sesuai dengan paragraf 36 .

PT Pembangunan Perumahan (Persero) Tbk dalam mengakui pendapatan atas jasa konstruksinya diakui berdasarkan persentase penyelesaian dan telah sesuai dengan PSAK No. 34 (Revisi 10).

Sedangkan pada pendapatan usaha konstruksiyang telah diterbitkan fakturnya diakui sebagai piutang usaha,sedangkan yang belum diterbitkan fakturnya diakui sebagaitagihan bruto pemberi kerja. Dalam PSAK No.34 Paragraf 22. Jika 
hasil kontrak konstruksi dapat diestimasi secara andal, maka pendapatan kontrak dan biaya kontrak yang berhubungan dengan kontrak konstruksi diakui masing-masing sebagai pendapatan dan beban dengan memerhatikan tahap penyelesaian aktivitas kontrak pada tanggal akhir periode pelaporan.. Hal ini tidak sejalan dengan penelitian Fitriana (2015) yang menyatakan bahwa dalam mengakui pendapatan perusahaan menerapkan metode kontrak selesai termasuk juga untuk proyek yang terjadi dalam dua periode, dan belum sesuai dengan PSAK No. 34 tentang kontrak kontruksi.

Pada PT Surya Semesta Internusa Tbk pendapatan diakui dengan menggunakan metodepersentase penyelesaian (percentage ofcompletion method) pada tanggal laporan posisi keuangan dan telah sesuai menurut PSAK No. 34 (Revisi 10).

Dalam hal ini persentase penyelesaian konstruksi ditetapkan berdasarkan kemajuan fisik.Beban jasa kontruksi meliputi biaya-biaya yangdapat diatribusikan kepada suatu kontrak untukjangka waktu sejak tanggal kontrak diperolehsampai dengan penyelesaian akhir kontrak dandiakui dalam laporan laba rugi komprehensifkonsolidasian tahun berjalan sesuai dengan hasilsurvei pekerjaan yang telah dilaksanakan. Dasar pengukuran dalam penyusunan laporankeuangan konsolidasian ini adalah konsep biayaperolehan (historical cost), kecuali beberapa akuntertentu disusun berdasarkan pengukuran lainsebagaimana diuraikan dalam kebijakan akuntansisetiap akun tersebut. Laporan keuangankonsolidasian disusun dengan asumsi kelangsunganusaha serta atas dasar akrual kecuali laporan aruskas.

Dalam Ningsih (2014) menyatakan bahwa perusahaan mengakui pendapatan dan beban berdasarkan kemajuan fisik, dapat dilihat bahwa pendapatan dan laba kotor diakui setiap periode berdasarkan kemajuan proses konstruksi serta perusahaan telah menggunakan metode persentase penyelesaian. Hal ini sesuai dengan PSAK No. 34 paragraf 25 .

Sedangkan pada PT Waskita Karya (Persero) Tbk pengakuan pendapatan jasa konstruksi diakui dengan menggunakan metode persentase penyelesaian (percentage of completion method) yang diukur berdasarkan kemajuan fisik pada tanggal akhir periode pelaporan yang dinyatakan dalam Berita Acara Penyelesaian Pekerjaan eksternal dan telah sesuai dengan PSAK No. 34 (Revisi 10). Akan tetapi pendapatan dari usaha perdagangan diakui hanya jika kemungkinan besar manfaat ekonomi sehubungan dengan transaksi tersebut akan mengalir ke entitas berdasarkan metode tahap penyerahan barang kepada pembeli, yang dinyatakan dalam PSAK 23 (Revisi 2010) tentang Pendapatan.
Hal ini tidak sejalan dengan penelitian yang dilakukan oleh Fitriana (2015) bahwa dalam mengakui pendapatan perusahaan menerapkan metode kontrak selesai termasuk juga untuk proyek yang terjadi dalam dua periode, dan belum sesuai dengan Pernyataan Standar Akuntansi Keuangan No. 34 tentang kontrak kontruksi. Sedangkan dalam pengakuan beban perusahaannya menggunakan metode accrual basis dan sudah sesuai dengan Pernyataan Standar Akuntansi Keuangan dimana pencatatan beban dilakukan agar tiap periode bisa melaporkan biaya atau beban yang sebenarnya.

Sedangkan penelitian ini sejalan dengan penelitian Ningsihi (2014) bahwa dengan menerapkan persentase penyelesaian dalam pengakuan pendapatan dan bebannya sehingga dapat diketahui laporan laba rugi yang disajikan oleh perusahaan sudah memenuhi prinsip matching concept dimana pendapatan yang diakui terdapat pula biaya yang diakui perusahaan dan telah sesuai dengan PSAK No. 34.

\section{SIMPULAN DAN SARAN}

\section{Simpulan}

Berdasarkan penelitian dan analisis yang telah dilakukan terhadap ketiga perusahaan, maka dapat disimpulkan hal-hal sebagai berikut:

1. Ketiga perusahaan yaitu PT Pembangunan Perumahan (Persero) Tbk, PT Surya Semesta Internusa Tbk, dan PT Waskita Karya (Persero) Tbk mengukur pendapatannya dengan menggunakan metode persentase penyelesaian (percentage of completion method) pada tanggal laporan posisi keuangan. Dalam hal ini persentase penyelesaian konstruksi ditetapkan berdasarkan kemajuan fisik.

2. Dari ketiga perusahaan tersebut yaitu PT Pembangunan Perumahan (Persero) Tbk, PT Surya Semesta Internusa Tbk, dan PT Waskita Karya (Persero) Tbk masing-masing memiliki tingkat jumlah pendapatan yang berbeda-beda setiap tahunnya. Hal ini juga berpengaruh terhadap jumlah laba dari masing-masing ketiga perusahaan. Pada kenyataannya, besarnya jumlah pendapatan tahun sebelumnya tidak menjamin akan meningkatnya jumlah laba tahun yang akan datang. Begitu pula sebaliknya, besarnya jumlah laba tahun sebelumnya tidak mempengaruhi kenaikan jumlah pendapatan tahun berikutnya. Kenaikan dan penurunan laba disetiap tahunnya atas proyek yang dilakukan karena perbedaan persentase pendapatan dan beban setiap terminnya.

3. PT Pembangunan Perumahan (Persero) Tbk, PT Surya Semesta Internusa Tbk, dan PT Waskita 
Karya (Persero) Tbk dalam melakukan pengakuan pendapatan menggunakan dasar accrual basis, hal ini telah sesuai dengan PSAK No. 34 yang berdasarkan accrual basis.

Sedangkan Pengakuan pendapatan serta metode pencatatan dan pengukuran yang diterapkan oleh PT Pembangunan Perumahan (Persero) Tbk, PT Surya Semesta Internusa Tbk, dan PT Waskita Karya (Persero) Tbk sudah sesuai dengan standard akuntansi yang berlaku yaitu Pernyataan Standard Akuntansi Keuangan (PSAK) dalam hal ini yang terkait dengan kontrak konstruksi adalah PSAK No. 34.

\section{Saran}

1. Memperluas objek penelitian yang digunakan dan pemperpanjang periode waktu penelitian.

2. Variabel yang digunakan dalam penelitian yang akan datang diharapkan menambah variabel independen lain diluar variabel yang digunakan penelitian saat ini seperti ukuran perusahaan dan pajak.

\section{DAFTAR PUSTAKA}

Ardiyos.(2011). Kamus Akuntansi Publik. Citra Harta Prima, Jakarta.

Datulangie, R.M., dan Poputra, A.T. (2015). Analisis Pengakuan Pendapatan Dan Beban Pada PT. Pegadaian (Persero) Cabang Megamas. Jurnal Universitas Sam Ratu langi ManadoVol 1 Nomor 2 Hal.4-11.

Fitriana,E.N. (2015). Analisis Atas Pengakuan Pendapatan Pada Perusahaan Jasa Konstruksi Kaitannya Terhadap Laporan Laba Rugi Perusahaan (Studi Kasus pada PT Intan Raya Yasoda). Jurnal Universitas Dian Nswantoro Vol 2 Nomor 2 Hal. 2-5.

Hanafi, M, dan Halim, A. (2012). Analisis Laporan Keuangan. Edisi Ketiga. Cetakan Pertama. Penerbit UPP Sekolah Tinggi Ilmu Manajemen YKPN. Yogyakarta.

Harahap, S.S. (2006). Analisa Kritis Atas Laporan Keuangan. PT Raja Grafindo Persada, Jakarta.

Harahap, S.S. (2011). Teori Akuntansi Edisi Revisi Cetakan Kelima. PT Raja Grafindo Persada, Jakarta.

Hasibuan, D.H.M, dkk. (2011). Evaluasi Atas pengakuan Pendapatan Pada Perusahaan Jasa Kontruksi Kaitannya Pada Laporan Laba Rugi Perusahaan (Studi Kasus Pada PT. Nusa Sukses Jaya). Jurnal Ilmiah Ranggagading Sekolah Tinggi Ilmu Ekonomi Kesatuan BogorVol 11 Nomor 2 Hal 142-149.

Hendriksen, V. B. (2002). Teori Akuntansi. Interaksa, Batam
Ikatan Akuntan Indonesia. (2015). Pernyataan Standar Akuntansi Keuangan. Salemba Empat, Jakarta.

Indriyanto, N., dan Supomo, B. (2014). Metodelogi Penelitian Bisnis: Untuk Manajemen dan Akuntansi. BPFE, Jogyakarta.

Kasmir.(2008). Analisis Laporan Keuangan. Raja Grafindo Persada, Jakarta.

Kieso, D. E, Jerry J. W, dan Terry D. W. (2002). Akuntansi Intermediate. Edisi 10, Jilid 3, Penerbit Erlangga, Jakarta.

Lestari, W., dan Dewi, I.S. (2016). Pengaruh Pengakuan Pendapatan Dan Beban Perusahaan Terhadap Laporan Laba Rugi Pada Perusahaan Konstruksi PT. Sumber Barokah. Jurnal Ilmiah Ekonomi dan Akuntansi Vol 1 Nomor 1 Hal 4-7.

Martono, dan Harjito, A. (2010). Manajemen Keuangan. Edisi Pertama. Cetakan Keempat. Penerbit Ekonisia, Yogyakarta.

Mulia, B. (2007). Analisis Pengakuan Pendapatan Dengan Persentase Penyelesaian Dalam Penyajian Laporan Keuangan PT. Pilar Dasar. Jurnal EMBA Universitas Sam Ratulangi. Manado Vol 1 Nomor 3 Hal 578-586.

Munawir. (2010). Analisa Laporan Keuangan. Edisi Keempat. Penerbit Liberty, Yogyakarta.

Ningsih, S.P. (2014). Analisis Atas Pengakuan Pendapatan Dan Beban Pada Perusahaan Jasa Konstruksi (Studi Kasus Pada CV. Taruna Bintan Tanjung pinang). Jurnal Akuntansi Universitas Martitim Raja Ali Haji, Tanjung pinang Vol 4 Nomor 2 Hal. 5-8.

Nuridawati,F.I.(2013). Analisa Pengakuan Dan Pengukuran Pendapatan Konstruksi Menurut PSAK No. 34 Pada PT. Starfindo Tunggal Pratama. Universitas Batam Vol 5 Nomor 3 Hal 139-152.

Pangestu, A.P. (2014). Pengakuan Pendapatan Dengan Pendekatan Metode Persentase Penyelesaian (Studi Kasus Pada Perusahaan PT. Bentan Sondong Tanjung pinang. Jurnal Fakultas Ekonomi Umrah, Tanjung pinang Vol 5 Nomor 3 Hal 8-12.

Pramurti, F.S. (2016). Analisis Pengakuan Pendapatan Jasa Konstruksi Pada CV. Indarchi Architect Team Klaten. Universitas Muhammadiyah Surakarta Vol 2 Nomor 4 Hal 23-29.

Prianthara,I.B.T. (2010). SistemAkuntansi Perusahaan Jasa Konstruksi. Edisi Pertama, Cetakan Pertama. Penerbit Graha Ilmu, Yogyakarta.

Ratuman,S.M.(2013). Analisis Pengakuan Pendapatan Dengan Persentase Penyelesaian Dalam Penyajian Laporan Keuangan PT. Pilar Dasar. Jurnal EMBA Universitas Sam 
Ratulangi ManadoVol 1 Nomor 3 Hal 578586.

Rezki, E. Y. (2016). Analisis Pengakuan Pendapatan Pada Perusahaan Jasa Konstruksi Berdasarkan PSAK No. 34. Universitas Muhammadiyah Malang Vol 1 Nomor 2 Hal 13-17.

Rismansyah dan Safitri, N. (2015). Analisis Pengakuan Pendapatan Dan Beban Pada PT. Wahana Bumi Riau Cabang Palembang. Jurnal MediaWahana Ekonomika, Vol 12 Nomor 2 Hal 51-74.

Sapto, R.W., dan Elly. (2012). Analisis Pengakuan Pendapatan Dan Beban Kontrak Pada UD. Gunawan Steel. Jurnal Manajemen dan Akuntansi STIE Banjarmasin Vol 13 Nomor 1 Hal 99-106.

Saputra, R., dan Effendi, R. (2013). Analisis Perlakuan Akuntansi Pendapatan Jasa Konstruksi Dalam Rangka Penyajian Laporan Keuangan Pada PT. Martimbang Utama Palembang. Jurnal STIE MDP Vol 2 Nomor 4 Hal 12-14.

Sarwono,J.2012. Metode Riset Skripsi Pendekatan Kuantitatif (Menggunakan Prosedur SPSS). PT Elex Media Komputindo, Jakarta.

Sawir. (2005). Analisis Kinerja Keuangan dan Perencanaan Keuangan Perusahaan. Cetakan Kelima. Penerbit PT. Gramedia Pustaka Utama, Jakarta.

Sitepu, W. S. (2014). Analisis Pengakuan Pendapatan dan Beban (Studi kasus pada kantor Notaris / PPAT Denilah Shofa Nasution, S.H, M.Kn). Jurnal Ilmiah Accounting Changes Vol 2 Nomor 1 Hal 16-25.

Skousen,S.(2009).Akuntansi Keuangan Edisi 16. Salemba Empat, Jakarta.

Sutrisno, (2009). Manajemen Keuangan (Teori, Konsep dan Aplikasi). Edisi Pertama. Cetakan Ketiga. Penerbit Ekonisia, Yogyakarta.

Syamsuddin,L. (2009). Manajemen Keuangan Perusahaan. Cetakan Sembilan. Penerbit Raja Grafindo Persada, Jakarta.

Warren, C. (2006). Pengantar Akuntansi Edisi Ke Duapuluh Satu Terjemahan. Salemba Empat, Jakarta

Yastiar, R. W. (2014). Pernyataan Standar Akuntansi Keuangan No.34 Yang Diterapkan Dalam Pengakuan Pendapatan Pada PT.PRESTA. Universitas Dian Nuswantoro Semarang Vol 3 Nomor 4 Hal 11-15. 
